\title{
WIEDZA POLSKICH SĘDZIÓW I PROKURATORÓW NA TEMAT PSYCHOLOGII ZEZNAŃ NAOCZNYCH ŚWIADKÓW W ŚWIETLE BADANIA WŁASNEGO
}

\section{WPROWADZENIE}

Kodeks postępowania karnego z 1997 r. w art. 7 normuje zasadę swobodnej oceny dowodów: „Organy postępowania kształtuja swe przekonanie na podstawie wszystkich przeprowadzonych dowodów, ocenianych swobodnie z uwzględnieniem zasad prawidłowego rozumowania oraz wskazań wiedzy i doświadczenia życiowego" 1 . Jest ona jedną z najważniejszych zasad procesowych, która powinna być stosowana na każdym etapie postępowania karnego: od jego wszczęcia aż do wydania prawomocnego wyroku lub innej decyzji procesowej. Zasada ta nabiera szczególnego znaczenia w momencie orzekania, gdy sąd musi brać ją pod uwagę przy wydawaniu zgodnego ze stanem faktycznym i sprawiedliwego wyroku. Tomasz Grzegorczyk i Janusz Tylman wskazuja, że zasada ta nie oznacza jednak pełnej dowolności w ocenie dowodów, gdyż „od organu procesowego wymaga się racjonalistycznego stosunku psychicznego do przedmiotu rozstrzygnięcia i dowodów".

Zasada swobodnej oceny dowodów wskazuje wyraźnie na konieczność równoważenia przez organ postępowania karnego trzech elementów wchodzacych w jej skład: zasad prawidłowego rozumowania, wskazań wiedzy oraz doświadczenia życiowego. Należy jednak pamiętać, że żaden ze środków dowodowych, nawet taki, który przyją postać tzw. dowodu naukowego ${ }^{3}$, nie ma statusu preferencyjnego, gdyż nadal podlega swobodnej ocenie dowodów przez organ procesowy. Bardzo często jednak sędziowie i prokuratorzy, podejmując decyzje procesowe, kładą większy nacisk na własne doświadczenie życiowe niż na wskazania wiedzy naukowej. Uważaja, że ich wieloletnia praktyka w zawodach prawniczych pozwala im podjać trafną decyzję bez korzystania z pomocy biegłych z danej dziedziny, a także bez koniecznych szkoleń.

1 Ustawa z 14 września 2018 r. - Kodeks postępowania karnego, t.jedn.: Dz. U. 2018, poz. 1987.

2 Grzegorczyk, Tylman (2014): 88.

${ }^{3}$ Szerzej na temat tzw. dowodu naukowego: Kwiatkowska-Wójcikiewicz, Wójcikiewicz (2009): 43-57. 
Brak podstawowej wiedzy psychologicznej dotyczącej takich zagadnień, jak wiarygodność zeznań naocznego świadka przestępstwa czy prawidłowego przeprowadzenia czynności okazania, podczas którego ofiara wskazała niewinną osobę jako swojego napastnika, może doprowadzić do tragicznej w skutkach pomyłki sądowej. Przykładem takiej pomyłki może być sprawa George’a Franklina, w 1990 r. skazanego za zabójstwo Susan Nason, które miał popełnić 20 lat wcześniej. Podstawą do skazania Franklina były zeznania jego córki, która przyjaźniła się z ofiarą. O całej sprawie córka skazanego „przypomniała sobie” podczas „transu hipnotycznego”, w który została wprowadzona podczas jednej z sesji psychoterapeutycznych. W $1996 \mathrm{r}$. prokuratura wycofała wszelkie zarzuty, gdyż żadne dowody nie wskazywały na winę skazanego, a sam Franklin został zwolniony z więzienia ${ }^{4}$. Do tego skazania zapewne by nie doszło, gdyby członkowie ławy przysięgłych, a przede wszystkim sędzia, znali wyniki badań, które wykazywały niską trafność hipnozy oraz niebezpieczeństwo wynikające z dużej podatności na sugestię osób zahipnotyzowanych ${ }^{5}$. Co więcej, badania aktowe prowadzone przez Elizabeth Loftus, amerykańską psycholog występująca jako biegły m.in. w sprawach niesłusznie skazanych, wykazały, że spośród 300 przeanalizowanych przez nią spraw, w których skazani okazali się niewinni, aż w $75 \%$ skazanie nastapiło wyłącznie na podstawie dowodu z zeznań naocznego świadka. Również Arye Rattner ${ }^{6}$, Barry Scheck i in..$^{7}$ oraz Michael Saks i Johnatan Koehler ${ }^{8}$ swoimi badaniami wykazali, że w sprawach, które kończą się skazaniem osoby niewinnej, w ok. 50\% przypadków wyrok skazujacy jest wynikiem błędu w zeznaniach naocznego świadka, niezauważonego przez niekompetentnego sędziego' ${ }^{9}$.

Psychologia, w tym psychologia zeznań naocznych świadków, jest skomplikowaną dyscypliną nauki, głównie ze względu na swój gwałtowny rozwój oraz pojawiające się nowe teorie dotyczące efektów i zjawisk psychologicznych, które mają w coraz większym stopniu tłumaczyć zachowanie człowieka, funkcjonowanie jego umysłu oraz sposobów podejmowania przez niego decyzji ${ }^{10}$. W obliczu dynamicznego rozwoju nauki pojawia się następujący problem: które z tych teorii można uznać za potwierdzone i powszechnie akceptowane przez środowisko naukowe, tak aby sędzia czy prokurator mógł się na nich oprzeć przy podejmowaniu decyzji procesowych? Amerykańscy psychologowie postanowili ustalić listę takich efektów i zjawisk związanych z psychologia zeznań naocznych świadków, które - zgodnie z testem Frye'a ${ }^{11}$ - należy uznać

${ }^{4}$ Lilienfeld et al. (2011): 124.

${ }^{5}$ Szerzej na ten temat: Lilienfeld et al. (2011): 171-172; Lynn, Green (2011): 277-293.

${ }^{6}$ Rattnera (1988).

7 Scheck, Neufeld, Dwyer (2000).

8 Saks, Koehler (2005).

${ }^{9}$ Magnussen et al. (2008): 177-188.

10 Szerzej na ten temat: Wieczorkowska-Wierzbińska (2011): 21-161; Tyszka (2000); Gruza (2012): 64-84.

${ }^{11}$ Test Frye'a został stworzony i po raz pierwszy wykorzystany w $1923 \mathrm{r}$. w sprawie Frye v. United States (293 F. 1013 D.C. Cir 1923). Pan Frye został oskarżony o zabójstwo drugiego stopnia, za co groziła mu kara wieloletniego pozbawienia wolności. Jako jeden z dowodów przemawiajacych na korzyść swojego klienta obrońca chciał przedstawić wyniki ekspertyzy wariograficznej. Ponieważ 
za w wystarczającym stopniu rozpowszechnione i akceptowane przez środowisko naukowe. W badaniach przeprowadzonych przez Saula Kassina i jego współpracowników w 1989 i 2001 r. udało się im stworzyć taką listę, która miała ułatwić pracę prawnikom w ogóle, a decydentom procesowym w szczególności ${ }^{12}$.

Należało sobie jednak zadać pytanie, czy prawnicy faktycznie skorzystali z wypracowanej przez psychologów listy i jaka wiedzę z zakresu psychologii zeznań naocznych świadków w ogóle posiadali. To pytanie dało asumpt do całej serii badań, przeprowadzonych najpierw w USA, a następnie w innych krajach kręgu common law.

Richard A. Wise i Martin A. Safer jako pierwsi przeprowadzili badanie, w którym zajęli się zagadnieniem wiedzy prawników, w tym przypadku amerykańskich sędziów, na temat psychologii zeznań. Uzyskane przez nich wyniki wykazały, że sędziowie posiadają relatywnie niska wiedzę z zakresu psychologii zeznań świadków, gdyż średnia liczba poprawnych odpowiedzi wyniosła tylko ok. 55\%. Wyniki niektórych sędziów wskazywały na ich niską wiedzę o prawidłowym przeprowadzeniu czynności okazania czy o procesach zapominania ${ }^{13}$.

Zespół Bentona zbadał wiedzę członków ławy przysięgłych, sędziów oraz funkcjonariuszy organów ścigania. Badanie to po raz kolejny wykazało braki w znajomości teorii i efektów z zakresu psychologii zeznań świadków, tym razem wskazując jednak na szczególnie zły stan wiedzy członków ławy przysięgłych, a więc tych osób, które w realiach amerykańskiego wymiaru sprawiedliwości swoim werdyktem decydują o czyjeś winie lub niewinności ${ }^{14}$.

Dalsze badania wykazały, że problem relatywnie niskiej wiedzy psychologicznej sędziów nie dotyczy tylko przedstawicieli amerykańskiego wymiaru sprawiedliwości. Svein Magnussen zbadał wiedzę psychologiczną sędziów norweskich i wykazał, że jest ona również relatywnie niska ${ }^{15}$. Podobne wyniki uzyskał także Wise i jego współpracownicy, sprawdzając wiedzę posiadaną przez chińskich sędziów ${ }^{16}$. Największą w tej serii badań wiedzę posiadali kanadyjscy laicy, mogący zasiadać w gronie sędziów przysięgłych. Uzyskany wynik badacze przypisywali jednak trochę inaczej skonstruowanemu przez siebie badaniu, a więc względom czysto metodologicznym, a nie faktycznej znajomości psychologii sądowej ${ }^{17}$.

jednak w tamtym czasie dowód ekspertyzy tego rodzaju nie był jeszcze dobrze opisany w literaturze fachowej, sąd stwierdził, że nie może uznać tego dowodu, gdyż „tego typu dowody naukowe powinny być wystarczająco rozpowszechnione, tak aby zyskały generalną akceptację w dziedzinie nauki, do której należą" (tłum. własne). Zawarty w uzasadnieniu wyroku standard uznawania dowodów naukowych został nazwany testem Frye'a i obowiąuje po dziś dzień w 8 stanach USA. Szerzej na ten temat: Kassin, Ellsworth, Smith (1989): 1089-1098; Kwiatkowska-Wójcikiewicz, Wójcikiewicz (2009): 43-57.

${ }^{12}$ Kassin et al. (1989): 1089-1098; (2001): 405-416.

13 Wise, Safer (2004): 429-440.

14 Benton et al. (2006): 115-129.

15 Magnussen et al. (2008): 177-188.

16 Wise et al. (2010): 695-713.

17 Read, Desmarais (2009): 301-326. 
Kolejne badania wykazały, że prokuratorzy i funkcjonariusze amerykańskiej policji również posiadali relatywnie niską wiedzę z zakresu psychologii zeznań naocznych świadków ${ }^{18}$. Interesujacy może być fakt, że przy słabym wyniku ogólnym, tylko $28 \%$ prokuratorów twierdziło, że przedstawiciele ich zawodu prawniczego mają ograniczoną wiedzę z zakresu psychologii zeznań naocznych świadków.

Wise i Safer wykazali także, że poziom wiedzy sędziów z zakresu psychologii zeznań naocznych świadków praktycznie nie różnił się od poziomu wiedzy studentów studiów I stopnia. Zwrócili też szczególną uwagę na wypowiedź jednego z profesorów, który twierdził, że na uczelni prawniczej, na której wykłada, studenci nie otrzymują praktycznie żadnych szkoleń z zakresu psychologii zeznań, a także - w jego opinii - w żadnej tego typu instytucji w USA nie prowadzi się zajęć na ten temat ${ }^{19}$.

Interesujące wyniki w sferze interakcji między prawem a psychologią przyniosły także badania polskie. Violetta Kwiatkowska-Wójcikiewicz oraz Józef Wójcikiewicz przeprowadzili badanie dotyczące opinii sędziów na temat dowodu naukowego, ich przygotowania do oceny takiego dowodu oraz trudności, z jakimi muszą się borykać przy jego ocenie. Autorzy wskazali, że: „w Polsce nie istnieją żadne standardy oceny dowodu naukowego i jak dotąd nie przeprowadzono gruntownych badań dotyczących postrzegania dowodu naukowego przez sędziów w związku z przygotowaniem do sprawowania wymiaru sprawiedliwości, w tym możliwości oceny dowodu naukowego, prezentowanego przez biegłych, przyczyn trudności etc." ${ }^{20}$. Analiza uzyskanych przez nich wyników pozwoliła autorom na wysnucie następujących wniosków: „1. sędziowie uważaja, że nie są dobrze przygotowani do oceny dowodów naukowych $(53 \%$ badanych); 2. swoją wiedzę czerpia głównie w drodze samokształcenia (literatura fachowa, Internet, orzecznictwo etc.); 3. aż 70\% badanych stwierdziło, że rzadko ma problem w ocenie opinii" ${ }^{1}$.

Zagadnieniem tzw. świadomości psychologicznej zajmowała się Marzanna Piekarska-Drążek, która sprawdzała, jakimi kryteriami w ocenie wiarygodności zeznań kierują się prawnicy praktycy w kontekście zmiany zeznań przez świadków w postępowaniu karnym. Przeprowadziła ona badanie na próbie 158 osób, w tym 107 prokuratorów oraz 51 sędziów, orzekających w wydziałach karnych sądów rejonowych i okręgowych centralnej i północno-wschodniej Polski. Wyniki badania pokazały, że uczestnicy najczęściej deklarowali kierowanie się osobistym doświadczeniem życiowym (26,6\% sędziów i $30,2 \%$ prokuratorów) oraz doświadczeniem zawodowym (18\% sędziów i $28,8 \%$ prokuratorów). Istotnym kryterium oceny wiarygodności zeznań wskazywanym przez respondentów była również intuicja (18\% sędziów i 14\% prokuratorów). Na znajomość psychologii wskazało tylko 3,1\% badanych ${ }^{22}$.

\footnotetext{
18 Wise et al. (2009): 1266-1281; Wise, Safer, Maro (2011): 488-500.

19 Wise, Safer (2010): 1400-1422.

${ }^{20}$ Kwiatkowska-Wójcikiewicz, Wójcikiewicz (2009): 44-46.

21 Kwiatkowska-Wójcikiewicz, Wójcikiewicz (2009): 56.

22 Piekarska-Drążek (2004): 168-169.
} 
Zagadnieniem wiedzy psychologicznej polskich prawników zajmowała się także Joanna Kabzińska. W artykule z 2015 r., dokładnie opisującym i podsumowującym przytoczone przeze mnie wcześniej badania zagraniczne, stwierdziła, że w Polsce brakuje systematycznych badań, które dotyczyłyby tego zagadnienia ${ }^{23}$. W badaniu z $2016 \mathrm{r}$. podjęła ona podjęła próbę znalezienia częściowej choćby odpowiedzi na pytanie, jaką wiedzą dotycząca psychologii zeznań naocznych świadków dysponują polscy prawnicy. Wzięło w nim udział ponad 70 aplikantów prokuratorskich oraz ponad 70 studentów prawa, których wiedza psychologiczna sprawdzana była za pomoca kwestionariusza zawierającego pozycje testowe zaczerpnięte z klasycznych badań Wise'a i Safera. Badanie wykazało, że aplikanci, a więc wkrótce zawodowi uczestnicy postępowania karnego, posiadali mniejszą wiedzą psychologiczną niż studenci prawa. Kabzińska wskazała jednak, że nie sposób na podstawie wyników jej badania wysnuć wniosków o wiedzy psychologicznej posiadanej przez faktycznie wykonujacych już swój zawód prawników, w tym w szczególności decydentów procesowych $^{24}$.

\section{BADANIE WLASNE}

\section{Procedura}

Badanie metodą kwestionariuszową (techniką PAPI) przeprowadzono w okresie od stycznia do kwietnia 2018 r. na próbie 87 sędziów i 193 prokuratorów. Badanie odbyło się za zgodą Dyrekcji Krajowej Szkoły Sądownictwa i Prokuratury w Krakowie podczas szkoleń ustawicznych, organizowanych przez Ośrodek Szkolenia Ustawicznego i Współpracy Międzynarodowej KSSiP w Ośrodku Szkoleniowym KSSiP w Dębem pod Warszawa. Zadaniem osób badanych było wskazanie, w jakim stopniu zgadzaja się z danym stwierdzeniem, oceniajac je na 5-stopniowej skali typu Likerta, od $1-$ zdecydowanie sie nie zgadzam do 5 - zdecydowanie sie zgadzam. Badani mieli także możliwość wskazania swojej niewiedzy $\mathrm{w}$ danej kwestii przez zaznaczenie odpowiedzi 3 - nie wiem. Za odpowiedź zdecydowanie się nie zgadzam, nie zgadzam się oraz nie wiem/ nie mam zdania $\mathrm{w}$ przypadku stwierdzenia zgodnego z prawda i stanem obecnej wiedzy naukowej badani otrzymywali 0 punktów. Za odpowiedź zgadzam się lub zdecydowanie się zgadzam w przypadku prawdziwego stwierdzenia badani otrzymywali 1 punkt.

\section{Narzędzie badawcze}

Stworzony na potrzeby badania „Kwestionariusz wiedzy z zakresu psychologii sądowej” (dalej jako: Kwestionariusz) składał się z 28 pozycji testowych (w kwestionariuszu dla sędziów - 29 pozycji), będących stwierdzeniami, dotyczącymi szeroko pojętej psychologii sądowej, psychologii zeznań naocznych

${ }^{23}$ Kabzińska (2015): 82.

${ }^{24}$ Kabzińska (2016): 394-407. 
świadków, a także często występujących mitów psychologicznych związanych z psychologia sądowa. W swojej zasadniczej części, sprawdzającej wiedzę psychologiczna, narzędzie zbudowano z trzech grup pozycji testowych, zaczerpniętych $\mathrm{z}$ trzech badań opisanych $\mathrm{w}$ literaturze fachowej. Dziesięć pozycji zostało zaczerpniętych $\mathrm{z}$ kwestionariusza wykorzystanego $\mathrm{w}$ oryginalnym badaniu Wise'a i Safera z 2010 r. ${ }^{25}$, kolejnych 8 pozycji pochodziło z kwestionariusza użytego w klasycznym badaniu Kassina i in. ${ }^{26}$ Ostatnich zaś 7 pozycji zostało wybranych z kwestionariusza wykorzystanego w badaniu Joachima Kowalskiego i in. ${ }^{27}$ Trzy ostatnie pytania dotyczyły oceny przez respondentów zakresu wiedzy sędziów, prokuratorów i policjantów z zakresu psychologii zeznań. W pozycjach zaczerpniętych z badań amerykańskich pytania zostały przetłumaczone przez autora.

Pozycje testowe użyte w Kwestionariuszu tworzyły trzy duże bloki tematyczne, będące jednocześnie obszarami wiedzy psychologicznej, która była weryfikowana podczas badania. W skład pierwszego obszaru związanego z percepcją i czynnikami, które mogą na nią wpływać, wchodziły takie pozycje, jak: Świadkowi jest zdecydowanie trudniej rozpoznać napastnika, który nosit czapkę podczas popetnienia przestepstwa niż napastnika, który nie miat czapki czy Stan nietrzeźwości może osłabić późniejsza zdolność naocznego świad$k a$ do przypominania sobie osób lub zdarzeń. W skład obszaru związanego z pamięcią oraz czynnikami wpływajacymi na zapamiętywanie i odtwarzanie wchodziły takie pozycje, jak: Zeznania naocznego świadka o zdarzeniu często odzwierciedlaja nie tylko to, co świadek rzeczywiście widziat, ale także informacje, które otrzymat później od innych świadków, Policji, z mediów itp. czy Spadek ilości zapamiętanego materiału jest największy zaraz po zdarzeniu, później spadek ten jest coraz mniejszy. Ostatni obszar wiedzy weryfikowany $\mathrm{w}$ opisywanym badaniu zwiąany był z przebiegiem procedur policyjnych oraz zasadami przeprowadzania czynności procesowo-kryminalistycznych z punktu widzenia psychologii. W skład tego obszaru tematycznego wchodziły takie pozycje, jak: Funkcjonariusz Policji, który wie, który z członków parady identyfikacyjnej jest osoba podejrzana, nie powinien prowadzić czynności okazania czy Zeznanie naocznego świadka o zdarzeniu może być zniekształcone przez to, jak sformułowane sa pytania mu zadawane. Dwie pozycje (Większość osób chorych psychicznie jest agresywna oraz Zahipnotyzowany zrobi wszystko, co każe mu zrobić hipnotyzer, może nawet popetnić przestęstwo) nie pasowały do żadnego z wyróżnionych obszarów.

\section{Próba badawcza}

W badaniu wzięło udział łącznie 545 osób, tworzących cztery grupy badawcze: sędziów, prokuratorów, studentów V roku prawa oraz grupa, w której skład również weszli studenci, ale reprezentujący kierunki studiów całkowicie niezwiązane z prawem lub psychologia.

25 Wise, Safer (2010): 1400-1422.

${ }^{26}$ Kassin et al. (2001): 405-416.

27 Kowalski et al. (2016): 100-112. 


\subsection{Sędziowie}

W badaniu wzięło udział 87 sędziów, w tym 51 kobiet i 35 mężczyzn, jedna osoba nie podała swojej płci (średni wiek $-M_{\text {wiek }}=43,07$ ). Średni staż pracy sędziów wynosił 13,16 roku, najkrótszy staż w przypadku jednego sędziego wynosił kilka miesięcy, najdłuższy zaś - 34 lata. Badani orzekali w większości (90\%) w sądach rejonowych, 7\% w sądach okręgowych i 3\% sądach apelacyjnych, w tym $96 \%$ w wydziałach karnych.

\subsection{Prokuratorzy}

W badaniu wzięło udział 193 prokuratorów, w tym 138 kobiet i 54 mężczyzn, jedna osoba nie podała swojej płci ('́redni wiek $-M_{\text {wiek }}=43,98$ ). Średni staż pracy prokuratorów wynosił 16,23 roku, najkrótszy staż w przypadku jednego prokuratora wynosił mniej niż rok, najdłuższy zaś 43 lata. Większość badanych (63\%) była zatrudniona w prokuraturach rejonowych, 30\% - w prokuraturach okręgowych i $7 \%$ - w prokuraturach regionalnych.

\subsection{Studenci V roku prawa}

W badaniu wzięło udział 148 studentów V roku prawa, w tym 93 kobiety i 55 mężczyzn ('́rredni wiek $-M_{\text {wiek }}=23,86$ ). Uczestnicy byli studentami dwóch uczelni wyższych: Uniwersytetu Mikołaja Kopernika w Toruniu (39\%) oraz Uniwersytetu Jagiellońskiego w Krakowie (61\%). Większość badanych (69\%) wskazała, że w toku swoich studiów nie miała zajęć z psychologii sądowej/ kryminalistycznej.

\subsection{Grupa studentów z kierunków innych niż prawo}

W badaniu wzięło udział 117 studentów, w tym 89 kobiet i 27 mężczyzn, jedna osoba nie podała swojej płci (średni wiek $-M_{\text {wiek }}=19,99$ ). Badani z grupy kontrolnej zostali wybrani celowo z takich kierunków, aby nie byli w żadnym stopniu związani z prawem lub psychologia, a także aby mogli reprezentować wiedzę całkowicie powszechną na temat zjawisk psychologii sądowej. W skład grupy kontrolnej weszło 48 studentów I roku studiów I stopnia biotechnologii, 28 studentów I roku studiów I stopnia geografii oraz 41 studentów I roku studiów I stopnia finansów i rachunkowości.

\section{WYNIKI}

\section{Wiedza sędziów, prokuratorów i studentów z zakresu psychologii zeznan}

Analiza wyników wykazała, że wszystkie grupy posiadają relatywnie przeciętna, czy wręcz niska, wiedzę dotycząca podstawowych zjawisk psychologii zeznań naocznych świadków. Ogólny średni wynik tego badania wyniósł 12,29 pkt, co stanowi mniej niż 50\% dobrych odpowiedzi. Średnie wyniki uzyskane przez 
poszczególne grupy badawcze wyniosły odpowiednio: sędziowie - 12,52 pkt, prokuratorzy $-12,11$ pkt, studenci V roku prawa - 13,03 pkt, uczestnicy wchodzacy w skład grupy studentów z kierunków innych niż prawo - 11,49 pkt.

Analiza przeprowadzona testem nieparametrycznym H Kruskala-Wallisa wykazała istotne statystycznie różnice między poszczególnymi grupami $(H=20,27 ; p<0,001)$. Dalsza analiza uzyskanych wyników między poszczególnymi grupami przeprowadzana była testem nieparametrycznym U Manna-Whitneya. W badaniu najlepsze wyniki uzyskali studenci prawa i ich średni wynik różnił się istotnie statystycznie od średniego wyniku prokuratorów $(U=11899,50 ; p=0,008)$ oraz studentów z innych kierunków niż prawo $(U=5991,50 ; p<0,001)$. Drugi w kolejności średni wynik uzyskali sędziowie i różnił się on istotnie statystycznie od średniego wyniku uzyskanego przez studentów nieprawników $(U=3906,00 ; p=0,004)$. Średni wynik uzyskany przez prokuratorów był istotnie statystycznie lepszy jedynie w przypadku porównania go ze średnim wynikiem grupy studentów z kierunków innych niż prawo $(U=9716,50 ; p=0,039)$. Wszystkie wyniki testów U Manna-Whitneya wraz z zaznaczeniem istotności statystycznej prezentuje tabela 1.

Tabela 1

Wyniki testów nieparametrycznych U Manna-Whitneya porównujących średnie wyniki uzyskane przez poszczególne grupy badawcze

\begin{tabular}{|l|c|c|c|c|}
\hline \multicolumn{1}{|c|}{$\begin{array}{c}\text { Grupy } \\
\text { badawcze }\end{array}$} & Sędziowie & Prokuratorzy & $\begin{array}{c}\text { Studenci } \\
\text { prawa }\end{array}$ & $\begin{array}{c}\text { Studenci } \\
\text { spoza prawa }\end{array}$ \\
\hline Sędziowie & - & & & \\
\hline Prokuratorzy & 7694,00 & - & & \\
\hline Studenci prawa & 5848,50 & $11899,50^{* *}$ & - & \\
\hline $\begin{array}{l}\text { Studenci } \\
\text { spoza prawa }\end{array}$ & $3906,00^{* *}$ & $9716,50^{*}$ & $5991,50^{* * *}$ & - \\
\hline
\end{tabular}

${ }^{*} p<0,05 ;{ }^{* *} p<0,01 ; * * * p<0,001$

Źródło: opracowanie własne.

\section{Porównania wewnątrz grup}

W przypadku sędziów liczba badanych, którzy byli zatrudnieni w sądach różnego szczebla, nie pozwoliła na przeprowadzenie trafnej analizy, która mogłaby dać odpowiedź na pytanie, czy zatrudnieni w sądach wyższego szczebla mają większą wiedzę na temat psychologii zeznań. Udało się taka analizę porównawczą przeprowadzić w przypadku prokuratorów, tzn. między prokuratorami zatrudnionymi w prokuraturach rejonowych a prokuratorami prokuratur okręgowych. Analiza przeprowadzona testem nieparametrycznym U Manna-Whitneya wykazała istotną różnicę między średnimi wynikami uzyskanymi przez wskazane grupy prokuratorów $(U=2698,00 ; p=0,019)-$ prokuratorzy zatrudnieni w prokuraturach okręgowych mieli mniejszą wiedzę od prokuratorów z prokuratur rejonowych. 


\section{Relacja między długością stażu pracy w zawodzie a uzyskanym średnim wynikiem w Kwestionariuszu przez sędziów i prokuratorów}

W przypadku sędziów analiza zgromadzonych wyników przeprowadzona testem $r$-Pearsona wykazała brak istotnej zależności między stażem pracy a uzyskanym wynikiem $(r=-0,04 ; p=0,700)$. W przypadku prokuratorów, analiza danych testem nieparametrycznym rho-Spearmana wykazała istotną zależność między stażem pracy a uzyskanym wynikiem ( $r h o=-0,16$; $p=0,023)$ - istnieje słaba odwrotna korelacja między tymi zmiennymi, co oznacza, że im dłuższy badani prokuratorzy mieli staż pracy, tym słabsze uzyskiwali wyniki.

\section{Ocena uczestników badania stanu wiedzy sędziów, prokuratorów i policjantów z zakresu psychologii zeznań}

Analiza odpowiedzi uczestników badania na pytanie o ocenę wiedzy sędziów, prokuratorów i policjantów, wykazała wyraźnie zjawisko przeceniania grupy własnej. W przypadku pytania o wiedzę sędziów przedstawiciele tego właśnie zawodu prawniczego ocenili siebie bardzo wysoko - prawie $50 \%$ badanych sędziów zgodziło się z tym stwierdzeniem. Prokuratorzy również wysoko oceniali własną grupę - ok. $60 \%$ badanych prokuratorów zgodziło się ze stwierdzeniem, że ich koleżanki i koledzy mają dobrą wiedzę o podstawowych mechanizmach psychologii zeznań. Interesujące było także sprawdzenie, czy istnieje związek między ocena grupy własnej a uzyskanym wynikiem przez danego badanego. W przypadku sędziów nie było żadnego związku między tymi zmiennymi, ale w przypadku prokuratorów można było zauważyć słaba odwrotną korelację $(r h o=-0,18 ; p=0,014)$ - im lepiej prokuratorzy oceniali wiedzę swojej grupy z zakresu psychologii zeznań, tym grosze otrzymywali wyniki na skali wiedzy psychologicznej.

\section{Skazanie a dowód z zeznania naocznego świadka}

Ostatnie pytanie w kwestionariuszu dla sędziów dotyczyło stopnia, w jakim byliby oni skłonni skazać oskarżonego, gdyby jedynym dowodem przemawiającym za jego winą było zeznanie naocznego świadka. Na tak postawione pytanie blisko $66 \%$ badanych sędziów udzieliło odpowiedzi twierdzącej.

\section{DYSKUSJA WYNIKÓW}

Analiza wyników opisywanego badania dotyczacego wiedzy sędziów, prokuratorów, studentów V roku prawa oraz laików na temat psychologii zeznań wykazała, że wszystkie te grupy posiadają relatywnie niską wiedzę z zakresu psychologii sądowej. 
Wart podkreślenia jest fakt, że najlepsze wyniki w badaniu osiagnęli studenci V roku prawa, reprezentujący Uniwersytet Jagielloński w Krakowie oraz Uniwersytet Mikołaja Kopernika w Toruniu. Ich średni wynik różnił się istotnie od wyników prokuratorów i studentów z kierunków innych niż prawo. Tak dobry, choć nadal należy pamiętać, że raczej przeciętny, wynik studentów V roku prawa może wynikać z faktu, że w toku swoich studiów mogli oni mieć na różnych zajęciach wprowadzane elementy psychologii sądowej, np. na zajęciach z postępowania karnego, postępowania cywilnego czy kryminalistyki.

\section{Sędziowie i prokuratorzy}

Wyniki przedstawionego badania zdają się obalać przekonanie wielu prawników, że samo doświadczenie zawodowe i życiowe nabywane przez lata praktyki gwarantuje posiadanie aktualnej wiedzy dotyczacej psychologii zeznań naocznych świadków. Do takiego przekonania odniósł się m.in. Józef Gurgul, pisząc, że „taka pewność jest wrogiem prawdy, o którą nieugięcie powinien [każdy decydent procesowy - M.G.] zabiegać" ${ }^{28}$. Badani prawnicy praktycy dysponują relatywnie przeciętną wiedzą psychologiczna, chociaż sami bardzo wysoko oceniają wiedzę swojej grupy zawodowej. Bliższa analiza udzielanych odpowiedzi na poszczególne pytania pozwala stwierdzić, że sędziowie i prokuratorzy maja duże braki w wiedzy, która może być im potrzebna podczas prawie każdej czynności procesowo-kryminalistycznej z udziałem osobowych źródeł dowodowych ${ }^{29}$.

Analiza liczby poprawnych odpowiedzi udzielonych przez sędziów i prokuratorów w pozycjach wchodzących w skład trzech bloków tematycznych, z których zbudowany był Kwestionariusz, pozwoliła na wskazanie, w jakich obszarach wiedzy psychologicznej największe braki mieli badani prawnicy. Uczestnicy badania najwięcej poprawnych odpowiedzi udzieli w pozycjach testowych związanych z percepcją i czynnikami, które mogą na nią wpływać (sędziowie - 80,75\%, prokuratorzy $-81,25 \%$ ).

Zdecydowanie większe braki w wiedzy psychologicznej uczestnicy badania wykazali w pozycjach wchodzacych w skład bloku związanego z pamięcia oraz czynnikami wpływającymi na zapamiętywanie i odtwarzanie (sędziowie $-43,25 \%$ poprawnych odpowiedzi, prokuratorzy $-39,75 \%)$. W ocenie wiarygodności zeznań badani prawnicy kierują się zdolnością świadka do przypominania sobie małych szczegółów dotyczących przestępstwa. Wyniki badań wskazuja jednak, że przypominanie sobie małych detali danego zdarzenia nie jest dobrym predyktorem trafności dokonanej identyfikacji i często może prowadzić wręcz do fałszywej identyfikacji ${ }^{30}$. Ponadto uczestnicy w przeważającej większości (93\% sędziów i 98\% prokuratorów!) zdają się wierzyć, że traumatyczne wspomnienia mogą być wyparte i przez wiele lat tłumione, a następnie odtworzone. Zjawisko to określa się w psychologii mianem amnezji

${ }^{28}$ Gurgul (2004): 16

29 Zob. załącznik 1.

${ }^{30}$ Szerzej na ten temat: Wells, Leippe (1981): 682-687; Bell, Loftus (1989): 669-679. 
dysocjacyjnej, a źródeł tej koncepcji należy szukać w pracach Zygmunta Freuda. Przeglądy badań empirycznych zwiąanych z wyparciem traumatycznych wspomnień, przeprowadzone przez Davida Holmesa w 1990 r. oraz Richarda McNally'ego w 2003 r., wykazały jednak, że nie ma żadnego przekonującego dowodu na istnienie amnezji dysocjacyjnej ${ }^{31}$.

W obszarze związanym z przebiegiem procedur policyjnych oraz zasadami przeprowadzania czynności procesowo-kryminalistycznych z punktu widzenia psychologii badani prawnicy również uzyskali relatywnie niskie wyniki (sędziowie - 43,45\% poprawnych odpowiedzi, prokuratorzy - 43,1\%). Prawie połowa badanych prawników uważa, że funkcjonariusze policji są lepszymi świadkami od zwyczajnego obywatela. W sytuacji „słowo przeciwko słowu”, gdy jedynym dowodem obciążajacym oskarżonego byłoby zeznanie policjanta, takie przeświadczenie mogłoby doprowadzić do skazania być może niewinnej osoby. Należy pamiętać, że funkcjonariusze policji dziennie dokonują kilku interwencji i z powodów czysto fizjologicznych oraz poznawczych trudno by im było dokładnie pamiętać każdą osobę i każde zdarzenie. Może być również tak, że część wspomnień nałoży się na siebie, doprowadzając do powstania fałszywego obrazu danego zdarzenia, o czym powinien pamiętać każdy sędzia przesłuchujący świadków często po kilku latach od popełnionego przestępstwa. Ponadto większość uczestników badania uważała, że szybkość dokonania identyfikacji jest dobrym predyktorem jej trafności, jednakże wyniki badań w tym zakresie jasno wskazuja, że nie można w łatwy sposób oddzielić identyfikacji trafnej od takiej, która powinna zostać uznana za niewiarygodna, biorac pod uwagę tylko czas, w jakim została dokonana ${ }^{32}$.

Badani prawnicy praktycy wierzą także w wiele mitów psychologicznych, nie są w tym jednak osamotnieni, gdyż badania pokazuja, że studenci V roku psychologii także w nie wierza. Mit psychologiczny zgodnie z definicją podawana przez Kowalskiego i in. - to „(a) ugruntowane przekonanie o psychice lub zachowaniu, (b) które przeczy dostępnej wiedzy naukowej, (c) jest używane do pojmowania i wyjaśniania rzeczywistości, a (d) jego obalenie jest konieczne do zdobywania autentycznej wiedzy". Prawnicy dużą wagę zdają się przywiązwać do profilowania kryminalnego oraz grafologii (wnioskowanie o cechach osobowości na podstawie charakteru pisma odręcznego) ${ }^{33}$, mimo że wiele badań wskazuje na ograniczoną rzetelność i trafność tych technik ${ }^{34}$. Może to być zwyczajnie spowodowanie rzadkim stosowaniem tych technik w realiach polskiego procesu karnego. Podobnie tłumaczyć można relatywnie mała wiedzę sędziów i prokuratorów dotyczaca hipnozy i jej użycia w postępowaniu karnym. Wynika to zapewne $\mathrm{z}$ faktu, że hipnoza nie jest zbyt często stosowana w procesie i dla prawników nadal pozostaje owiana nimbem tajemnicy. Jednakże w takiej sytuacji należałoby zachować daleko idący sceptycyzm i zasadę „ograniczonego zaufania”, a nie ulegać zbiorowej fascynacji hipnoza, o czym

31 Lilienfeld et al. (2011) 134-136.

${ }^{32}$ Weber et al. (2004): 139-147.

33 Kowalski et al. (2016): 100-112. Zob. też załącznik 1.

${ }^{34}$ Lilienfeld et al. (2011): 285-290, 340-343; Kocsis, Hayes, Irwin (2002): 811-823; Dean et al. (1992): 342-396. 
pisał Józef Wójcikiewicz ${ }^{35}$. Eysenck stwierdził, że mało jest takich tematów w historii ludzkości, które doprowadziłyby do powstania tylu nieporozumień i bredni, jak właśnie hipnoza ${ }^{36}$.

$\mathrm{W}$ przypadku sędziów istotne wnioski wynikaja z analizy odpowiedzi na pytanie, w jakim stopniu byliby skłonni skazać oskarżonego, gdyby jedynym dowodem przemawiającym za jego winą było zeznanie naocznego świadka. Pytanie to samo w sobie zawiera mało informacji o tym zeznaniu - czy było wiarygodne, pełne, drobiazgowe, pewne? Sędziowie mogli zaznaczyć odpowiedź nie wiem/ nie mam zdania, wyrażając swój sceptycyzm i pamiętając o ograniczeniach związanych z zeznaniami naocznego świadka. Tymczasem aż $66 \%$ badanych sędziów wydałoby w takiej sytuacji wyrok skazujący.

\section{Możliwe wyjaśnienia}

Z czego więc może wynikać tak słaby wynik prawników praktyków i studentów? Przede wszystkim może być to konsekwencją braku zajęć z psychologii sądowej/ kryminalistycznej w toku studiów. Analiza programów jednolitych studiów magisterskich prawa, prowadzonych przez 12 najlepszych wydziałów prawa i administracji w Polsce według rankingu „Rzeczypospolitej” za rok $2017^{37}$ (w tym UMK i UJ), wykazuje, że na żadnym z tych wydziałów nie ma obligatoryjnych zajęć z psychologii sądowej lub kryminalistycznej. Zajęcia związane $\mathrm{z}$ ta tematyka sa zawsze jedynie zajęciami fakultatywnymi lub specjalistycznymi, na które nie muszą chodzić wszyscy studenci. Jeżeli już na danym wydziale realizowane są zajęcia z psychologii, to poruszane na nich zagadnienia dotycza głównie psychologii ogólnej, historii psychologii oraz psychologii społecznej. Stąd należy brać pod uwagę smutny i niepokojący zarazem wniosek, że przeciętny absolwent prawa opuszcza mury uczelni bez jakiegokolwiek przygotowania psychologicznego do pracy w swoim wymarzonym zawodzie.

W toku aplikacji nie prowadzi się zajęć z zakresu psychologii sądowej lub jedynie porusza się wybrane problemy, takie jak: psychologiczne aspekty przesłuchania dziecka bądź pokrzywdzonego/ pokrzywdzonej przestępstwem przeciwko wolności seksualnej czy ekspertyza psychologiczna. Kolejny etap edukacji, czyli szkolenia ustawiczne dla sędziów i prokuratorów, również nie daje prawnikom gwarancji zdobycia odpowiedniej i aktualnej wiedzy. Sami prawnicy często uważaja, że wiedza psychologiczna przyjdzie sama, dzięki przeprowadzonym przesłuchaniom i czynnościom okazania. Tymczasem wyniki prezentowanego badania wykazały, że staż pracy nie wpływa pozytywnie na poziom wiedzy, może powodować jej obniżenie, jak w przypadku badanych prokuratorów.

Wiedza $\mathrm{z}$ innych dziedzin nauki poza prawem nie jest brana pod uwage w procesie powoływania sędziów. Autorzy raportu dotyczącego procesu selek-

35 Wójcikiewicz (1989): 134-135.

36 Eysenck (1965): 27.

37 Zob. <https://www.wpia.uni.lodz.pl/aktualnosci/komunikaty/ranking-wydzialow-prawa-2017-dziennika-rzeczpospolita.html> [dostęp: 29.04.2018]. 
cji kandydatów na wolne stanowiska sędziowskie wskazuja, że najważniejsze elementy brane pod uwagę przez Krajową Radę Sądownictwa to stabilność orzecznicza oraz organizacja pracy przez danego sędziego. Dyplomy i certyfikaty poświadczające ukończenie dodatkowych szkoleń mają o wiele mniejsze znaczenie ${ }^{38}$, podobnie jest $\mathrm{z}$ predyspozycjami osobowościowymi oraz kompetencjami społecznymi kandydata ${ }^{39}$.

\section{PODSUMOWANIE}

Przeprowadzone badanie wykazało, że polscy prawnicy - sędziowie, prokuratorzy oraz studenci V roku prawa - dysponują relatywnie niską wiedza z zakresu psychologii zeznań naocznych świadków. Badanie to wykazało także, że polscy prawnicy nie różnią się zbytnio poziomem wiedzy psychologicznej od ich zagranicznych odpowiedników. Pamiętać jednak należy, że amerykańscy sędziowie decyduja jedynie o karze, orzeczenie o winie wydają członkowie ławy przysięgłych. Polski sędzia orzeka o obu tych elementach, w związku z czym powinien on, przynajmniej teoretycznie, posiadać lepszą wiedzę od sędziego amerykańskiego. Mimo licznych różnic w samych systemach prawnych - common i civil law - prawnicy z dwóch różnych kontynentów zdają się jednak mieć podobne braki w wiedzy dotyczącej psychologii zeznań.

Kabzińska w konkluzji swojego artykułu zwraca uwagę, że tylko „od przedstawicieli wymiaru sprawiedliwości zależy, czy będą chcieli i potrafili z tej wiedzy [psychologicznej - M.G.] skorzystać" ${ }^{\prime 4}$. Podczas przeprowadzania opisywanego w niniejszym artykule badania uczestnicy wskazywali, że widzą braki w swojej wiedzy. Respondenci zaznaczali także, że bardzo chcą się szkolić w dziedzinie psychologii sądowej, gdyż dostrzegają jej ogromną rolę w stosowaniu prawa. Aktualny system edukacji prawniczej - studia, aplikacja oraz szkolenia ustawiczne - nie pozwala jednak przyszłym prawnikom oraz decydentom procesowym na zdobycie aktualnej wiedzy na temat psychologii zeznań, koniecznej do wykonywania przez nich zawodu. Rodzi to potencjalne niebezpieczeństwo podjęcia przez nich błędnych decyzji procesowych. Trudno bowiem wyobrazić sobie proces karny bez wykorzystania osobowych źródeł dowodowych, trudno także przecenić wiarygodne zeznanie naocznego świadka. Obowiązek oceny tej wiarygodności leży po stronie sędziego i prokuratora, dlatego powinni być oni zawsze świadomi możliwości zniekształceń takiego zeznania oraz płynących z tego faktu zagrożeń.

Michat Gtówczewski

Uniwersytet Mikołaja Kopernika w Toruniu

michal.glowczewski@doktorant.umk.pl

https://orcid.org/0000-0001-7449-4232

38 Pilitowski, Hoffman, Kociołowicz-Wiśniewska (2017): 51-53.

39 Pilitowski, Hoffman, Kociołowicz-Wiśniewska (2017): 59-61.

${ }^{40}$ Kabzińska (2015): 84. 
Bell, B.E., Loftus, E.F. (1989). Trivial persuasion in the courtroom: the power of (a few) minor details. Journal of Personality and Social Psychology 56(5): 669-679.

Benton, T.R., Ross, D.F., Bradshaw, E., Thomas, W.N., Bradshaw, G.S. (2006). Eyewitness memory is still not common sense: comparing jurors, judges and law enforcement to eyewitness experts. Applied Cognitive Psychology 20(1): 115-129.

Dean, G.A., Kelly, I.W., Saklofske, D.H., Furnham, A. (2002). Graphology and human judgment, [w:] B.L. Beyersteini, D.F. Beyerstein (eds.), The Write Stuff: Evaluations of Graphology, the Study of Handwriting Analysis. Amherst-New York: PrometheusBooks: 342-396.

Eysenck, H.J. (1965). Sens i nonsens w psychologii. Tłum. M. Brzezińska. Warszawa: PWN.

Gruza, E. (2012). Psychologia sądowa dla prawników. Wyd. 2. Warszawa: Wydawnictwo Wolters Kluwer.

Grzegorczyk, T., Tylman, J. (2014). Polskie postępowanie karne. Wyd. 9. Warszawa: Wolters Kluwer.

Gurgul, J. (2004). Wybrane problemy w kontaktach organu procesowego z biegłym. Problemy Kryminalistyki 244: 16-24.

Kabzińska, J. (2015). Wiedza prawników o psychologii zeznań świadków. Prokuratura i Prawo 6: $75-85$.

Kabzińska, J. (2016). Prosecutor apprentices and laypeople's knowledge on eyewitness testimony issues. Problems of Forensic Sciences 105: 394-407.

Kassin, S.M., Ellsworth, P.C., Smith V.L. (1989). The "general acceptance" of psychological research of eyewitness testimony. A survey of experts. American Psychologist 44(8): 1089-1098.

Kassin, S.M., Tubb, V.A., Hosch, H.M., Memon, A. (2001). On the "general acceptance" of eyewitness psychological research. The new survey of the experts. American Psychologist 56(5): 405-416.

Kocsis, R.N., Hayes, A.F., Irwin, H.J. (2002). Investigative experience and accuracy in psychological profiling of a violent crime. Journal of Interpersonal Violence 17(8): 811-823.

Kowalski, J., Litwin, P., Pankowski, D., Cierpka, A. (2016). Mity psychologiczne wśród studentów psychologii. Edukacja 2(137): 100-112.

Kwiatkowska-Wójcikiewicz, V., Wójcikiewicz, J. (2009). Sędziowie wobec dowodu naukowego, [w:] J. Kasprzak, B. Młodziejowski (red.), Kryminalistyka i inne nauki pomostowe w postępowaniu karnym. Olsztyn: PrintGroup 43-57.

Lilienfeld, S.O., Lynn, S.J., Ruscio, J., Beyerstein, B.L. (2011). 50 wielkich mitów psychologii popularnej. Półprawdy, ćwierćprawdy i kompletne bzdury. Warszawa-Stare Groszki: Wydawnictwo CiS.

Lynn, S., Green, J. (2011). The sociocognitive and dissociation theories of hypnosis: toward a rapprochement. International Journal of Clinical and Experimental Hypnosis 59(3): 277-293.

Magnussen, S., Melinder, A., Stridbeck, U., Raja, A.Q. (2010). Beliefs about factors affecting the reliability of eyewitness testimony: a comparison of judges, jurors and the general public. Applied Cognitive Psychology 24(1): 122-133.

Magnussen, S., Wise, R.A., Raja, A.Q., Safer, M.A., Pawlenko, N., Stridbeck, U. (2008). What judges know about eyewitness testimony: a comparison of Norwegian and US judges. Psychology, Crime \& Law 14(3): 177-188.

Piekarska-Drążek, M. (2004). Zmiana zeznań świadków w procesie karnym. Problemy Współczesnej Kryminalistyki 8: 145-172.

Pilitowski, B., Hoffman, M., Kociołowicz-Wiśniewska, B. (2017). Skąd się biorą sędziowie? Raport z badania procesu selekcji kandydatów na wolne stanowiska sędziowskie przez Krajowa Radę Sądownictwa. Toruń.

Rattner, A. (1988). Convicted but innocent: wrongful conviction and the criminal justice system. Law and Human Behavior 12(3): 283-293.

Read, J.D., Desmarais, S.L. (2009). Lay knowledge of eyewitness issues: a Canadian evaluation. Applied Cognitive Psychology 23(3): 301-326.

Saks, M.J., Koehler, J.J. (2005). The coming paradigm shift in forensic identification science. Science 309(5736): 892-895.

Scheck, B., Neufeld, P., Dwyer, J. (2000). Actual Innocence: Five Days to Execution and Other Dispatches from the Wrongly Convicted. New York: Doubleday.

Skorupka, J. (red.) (2018). Kodeks postępowania karnego. Komentarz. Wyd. 3. Warszawa. <http:// sip-1legalis-1pl100bd6bsu0e8a.han3.uci.umk.pl/documentview.seam?documentId=mjxw62zogi3damjxg42tqmjoobqxalrugazdaojsha2a> [dostęp: 29.12.2017].

Tyszka, T. (2000). Psychologiczne pułapki oceniania i podejmowania decyzji. Gdańsk: Gdańskie Wydawnictwo Psychologiczne. 
Weber, N., Brewer, N., Wells, G.L., Semmler, C., Keast, A. (2004). Eyewitness identification accuracy and response latency: the unruly 10-12-second rule. Journal of Experimental Psychology 10(3): 139-147.

Wells, G.L., Leippe, M.R. (1981). How do triers of fact infer the accuracy of eyewitness identifications? Using memory for peripheral detail can be misleading. Journal of Applied Psychology 66(6): 682-687.

Wieczorkowska-Wierzbińska, G. (2011). Psychologiczne ograniczenia. Warszawa: Wydawnictwo Naukowe Wydziału Zarządzania Uniwersytetu Warszawskiego.

Wise, R.A., Safer, M.A. (2004). What US judges know and believe about eyewitness testimony. Applied Cognitive Psychology 18(4): 429-440.

Wise, R.A., Safer, M.A. (2010). A comparison of what U.S. judges and students know and believe about eyewitness testimony. Journal of Applied Social Psychology 40(6): 1400-1422.

Wise, R.A., Pawlenko, N.B., Safer, M.A., Meyer D. (2009). What US prosecutors and defense attorneys know and believe about eyewitness testimony. Applied Cognitive Psychology 23(9): 1266-1281.

Wise, R.A., Safer, M.A., Maro, Ch.M. (2011). What U.S. law enforcement officers know and believe about eyewitness factors, eyewitness interviews and identification procedures. Applied Cognitive Psychology 25(3): 488-500.

Wójcikiewicz, J. (1989). Hipnoza w prawie karnym i kryminalistyce. Kraków: Uniwersytet Jagielloński.

\section{THE KNOWLEDGE OF POLISH JUDGES AND PROSECUTORS CONCERNING THE PSYCHOLOGY OF EYEWITNESS TESTIMONY}

\section{Sum mary}

Knowledge of psychology is vital in the application of law. However, classical studies by Richard A. Wise and Martin A. Safer (conducted on a sample of American judges, prosecutors and attorneys) showed that they know very little about psychological effects in eyewitness testimony. Further studies conducted in Norway, Canada and China arrived at similar conclusions. This article presents results of the author's own study, which was the first attempt to verify the knowledge of Polish judges and prosecutors concerning the psychology of eyewitness testimony. Research was conducted on a sample of 545 participants, including 87 judges and 193 prosecutors. The results showed that Polish lawyers also know rather little about the psychology of eyewitness testimony. The results suggest that the professional experience of judges and prosecutors does not in itself always guarantee they have actual knowledge about the psychology of eyewitness testimony.

Keywords: forensic psychology; psychology and law; lawyer's knowledge of psychology; psychology of eyewitness testimony

\section{Załącznik 1}

Odsetek poprawnych odpowiedzi udzielonych przez uczestników badania

\begin{tabular}{|c|l|c|c|c|c|}
\hline Lp. & \multicolumn{1}{|c|}{ Stwierdzenie } & Sędziowie & $\begin{array}{c}\text { Prokura- } \\
\text { torzy }\end{array}$ & $\begin{array}{c}\text { Studenci } \\
\text { V roku } \\
\text { prawa }\end{array}$ & $\begin{array}{c}\text { Grupa } \\
\text { kontrolna }\end{array}$ \\
\hline 1 & $\begin{array}{l}\text { Świadkowi jest zdecydowanie } \\
\text { trudniej rozpoznać } \\
\text { napastnika, który nosił } \\
\text { czapkę podczas popełnienia } \\
\text { przestęstwa, niż } \\
\text { napastnika, który nie miał } \\
\text { czapki }\end{array}$ & $74 \%$ & $69 \%$ & $68 \%$ & $77 \%$ \\
\hline
\end{tabular}




\begin{tabular}{|c|c|c|c|c|c|}
\hline Lp. & Stwierdzenie & Sędziowie & $\begin{array}{c}\text { Prokura- } \\
\text { torzy }\end{array}$ & $\begin{array}{l}\text { Studenci } \\
\text { V roku } \\
\text { prawa }\end{array}$ & $\begin{array}{c}\text { Grupa } \\
\text { kontrolna }\end{array}$ \\
\hline 2 & $\begin{array}{l}\text { Zdolność świadka do } \\
\text { przypomnienia sobie małych } \\
\text { szczegółów dotyczących } \\
\text { przestępstwa jest dobrym } \\
\text { wskaźnikiem trafności } \\
\text { dokonanej przez niego } \\
\text { identyfikacji napastnika }\end{array}$ & $13 \%$ & $19 \%$ & $35 \%$ & $10 \%$ \\
\hline 3 & $\begin{array}{l}\text { Nastawienie i oczekiwania } \\
\text { naocznego świadka } \\
\text { przestępstwa moga mieć } \\
\text { wpływ na jego percepcję } \\
\text { i pamięć o zdarzeniu }\end{array}$ & $93 \%$ & $92 \%$ & $89 \%$ & $81 \%$ \\
\hline 4 & $\begin{array}{l}\text { Funkcjonariusz Policji, który } \\
\text { wie, który z członków parady } \\
\text { identyfikacyjnej jest osoba } \\
\text { podejrzana, nie powinien } \\
\text { prowadzić czynności } \\
\text { okazania }\end{array}$ & $70 \%$ & $59 \%$ & $70 \%$ & $43 \%$ \\
\hline 5 & $\begin{array}{l}\text { Podczas rozprawy, pewność } \\
\text { świadka jest dobrym } \\
\text { predyktorem jego trafności } \\
\text { w identyfikacji oskarżonego } \\
\text { jako napastnika }\end{array}$ & $36 \%$ & $28 \%$ & $39 \%$ & $24 \%$ \\
\hline 6 & $\begin{array}{l}\text { Zeznania naocznego } \\
\text { świadka o zdarzeniu często } \\
\text { odzwierciedlaja nie tylko } \\
\text { to, co świadek rzeczywiście } \\
\text { widział, ale także informacje, } \\
\text { które otrzymał później od } \\
\text { innych świadków, Policji, } \\
\text { z mediów itp. }\end{array}$ & $81 \%$ & $80 \%$ & $86 \%$ & $79 \%$ \\
\hline 7 & $\begin{array}{l}\text { Naoczni świadkowie czasami } \\
\text { identyfikuja jako sprawcę } \\
\text { kogoś, kogo widzieli w innej } \\
\text { sytuacji lub kontekście }\end{array}$ & $59 \%$ & $54 \%$ & $66 \%$ & $57 \%$ \\
\hline 8 & $\begin{array}{l}\text { Funkcjonariusze Policji sa } \\
\text { bardziej trafni w zeznaniach } \\
\text { jako naoczni świadkowie niż } \\
\text { zwykła osoba }\end{array}$ & $54 \%$ & $48 \%$ & $46 \%$ & $38 \%$ \\
\hline 9 & $\begin{array}{l}\text { Traumatyczne doświadczenia } \\
\text { moga być tłumione przez } \\
\text { wiele lat i później odtworzone }\end{array}$ & $7 \%$ & $2 \%$ & $3 \%$ & $3 \%$ \\
\hline 10 & $\begin{array}{l}\text { Obecność broni może osłabić } \\
\text { zdolność świadka do trafnego } \\
\text { zidentyfikowania twarzy } \\
\text { napastnika }\end{array}$ & $67 \%$ & $69 \%$ & $77 \%$ & $68 \%$ \\
\hline 11 & $\begin{array}{l}\text { Im szybciej świadek dokona } \\
\text { identyfikacji podczas } \\
\text { okazania, tym bardziej ta } \\
\text { identyfikacja jest trafna }\end{array}$ & $40 \%$ & $35 \%$ & $27 \%$ & $22 \%$ \\
\hline
\end{tabular}




\begin{tabular}{|c|c|c|c|c|c|}
\hline Lp. & Stwierdzenie & Sędziowie & $\begin{array}{l}\text { Prokura- } \\
\text { torzy }\end{array}$ & $\begin{array}{l}\text { Studenci } \\
\text { V roku } \\
\text { prawa }\end{array}$ & $\begin{array}{c}\text { Grupa } \\
\text { kontrolna }\end{array}$ \\
\hline 12 & $\begin{array}{l}\text { Pokazanie świadkowi } \\
\text { zdjęć policyjnych } \\
\text { podejrzanego zwiększa } \\
\text { prawdopodobieństwo } \\
\text { wskazania go później przez } \\
\text { świadka podczas okazania }\end{array}$ & $81 \%$ & $80 \%$ & $82 \%$ & $84 \%$ \\
\hline 13 & $\begin{array}{l}\text { Profilowanie psychologiczne } \\
\text { to skuteczne narzędzie, } \\
\text { prowadzące do wykrycia } \\
\text { sprawcy przestępstwa }\end{array}$ & $10 \%$ & $11 \%$ & $6 \%$ & $2 \%$ \\
\hline 14 & $\begin{array}{l}\text { Za pomoca hipnozy można } \\
\text { dotrzeć do wypartych } \\
\text { wspomnień z dzieciństwa }\end{array}$ & $16 \%$ & $7 \%$ & $19 \%$ & $25 \%$ \\
\hline 15 & $\begin{array}{l}\text { Świadkowie częściej } \\
\text { popełnią błąd w identyfikacji } \\
\text { sprawcy, gdy okazanie będzie } \\
\text { symultaniczne (wszyscy na } \\
\text { raz) niz sekwencyjne (jeden } \\
\text { po drugim) }\end{array}$ & $18 \%$ & $22 \%$ & $26 \%$ & $29 \%$ \\
\hline 16 & $\begin{array}{l}\text { Spadek ilości zapamiętanego } \\
\text { materiału jest największy } \\
\text { zaraz po zdarzeniu, później } \\
\text { spadek ten jest coraz } \\
\text { mniejszy }\end{array}$ & $43 \%$ & $32 \%$ & $53 \%$ & $60 \%$ \\
\hline 17 & $\begin{array}{l}\text { Stan nietrzeźwości może } \\
\text { osłabić późniejszą zdolność } \\
\text { naocznego świadka do } \\
\text { przypominania sobie osób lub } \\
\text { zdarzeń }\end{array}$ & $89 \%$ & $95 \%$ & $95 \%$ & $93 \%$ \\
\hline 18 & $\begin{array}{l}\text { Wariograf (tzw. wykrywacz } \\
\text { kłamstw) to skuteczne } \\
\text { narzędzie do określenia, czy } \\
\text { świadek kłamie }\end{array}$ & $51 \%$ & $56 \%$ & $47 \%$ & $32 \%$ \\
\hline 19 & $\begin{array}{l}\text { Użycie hipnozy jest } \\
\text { przydatne w przypadku } \\
\text { świadka przypominającego } \\
\text { sobie szczegóły przestępstwa }\end{array}$ & $32 \%$ & $32 \%$ & $35 \%$ & $34 \%$ \\
\hline 20 & $\begin{array}{l}\text { Małe dzieci są bardziej } \\
\text { podatne na sugestię } \\
\text { przesłuchujacego, nacisk } \\
\text { grupy rówieśniczej i inne } \\
\text { rodzaje wpływu społecznego } \\
\text { niż dorośli }\end{array}$ & $95 \%$ & $92 \%$ & $82 \%$ & $85 \%$ \\
\hline 21 & $\begin{array}{l}\text { Psychologiczna analiza } \\
\text { odręcznego pisma pozwala } \\
\text { ustalić cechy osobowości } \\
\text { danej osoby }\end{array}$ & $12 \%$ & $16 \%$ & $20 \%$ & $12 \%$ \\
\hline
\end{tabular}




\begin{tabular}{|c|c|c|c|c|c|}
\hline Lp. & Stwierdzenie & Sędziowie & $\begin{array}{l}\text { Prokura- } \\
\text { torzy }\end{array}$ & $\begin{array}{c}\text { Studenci } \\
\text { V roku } \\
\text { prawa }\end{array}$ & $\begin{array}{c}\text { Grupa } \\
\text { kontrolna }\end{array}$ \\
\hline 22 & $\begin{array}{l}\text { Hipnoza zwiększa } \\
\text { podatność na sugestię } \\
\text { w naprowadzających } \\
\text { i mylących pytaniach }\end{array}$ & $15 \%$ & $26 \%$ & $32 \%$ & $25 \%$ \\
\hline 23 & $\begin{array}{l}\text { Zeznanie naocznego świadka } \\
\text { o zdarzeniu może być } \\
\text { zniekształcone przez to, jak } \\
\text { sformułowane są pytania mu } \\
\text { zadawane }\end{array}$ & $91 \%$ & $93 \%$ & $90 \%$ & $84 \%$ \\
\hline 24 & $\begin{array}{l}\text { Większość osób chorych } \\
\text { psychicznie jest agresywna }\end{array}$ & $85 \%$ & $81 \%$ & $72 \%$ & $56 \%$ \\
\hline 25 & $\begin{array}{l}\text { Zahipnotyzowany zrobi } \\
\text { wszystko, co każe mu zrobić } \\
\text { hipnotyzer, może nawet } \\
\text { popełnić przestępstwo }\end{array}$ & $21 \%$ & $25 \%$ & $41 \%$ & $29 \%$ \\
\hline
\end{tabular}

Źródło: opracowanie własne. 